\title{
THE STUDY OF THE ACTION OF THE THICK EXTRACT FROM THE LEAVES OF CORYLUS AVELLANA ON THE VASCULAR TISSUE PERMEABILITY
}

\author{
L.M.Maloshtan, G.S.Kalenichenko, O.V.Dorovskyy*
}

\author{
National University of Pharmacy \\ Institute for Continuing Education of Pharmacy Professionals at the National University \\ of Pharmacy*
}

Key words: extract from the leaves of Corylus avellana; medicinal plants; varicose veins; capillary resistance activity

\begin{abstract}
The study of the action of the thick extract from the leaves of Corylus avellana on the vascular tissue permeability of the rat's skin has been conducted. The effect of the thick extract from the leaves of Corylus avellana on the vascular tissue permeability in rats has been assessed by the time of papules colouring (the animals' skin at the site of phlogogenic substances injection) in seconds. As phlogogens formalin, histamine, protein, which have different mechanisms of action on the capillary permeability, have been used. In the group where the extract studied was introduced in its conditional therapeutic dose of $60 \mathrm{mg} / \mathrm{kg}$ the decrease of the vascular permeability induced by phlogogenic substances was observed. It has been determined that the extract has the most pronounced vessel strengthening effect in the experiment with histamine where papules colouring is 1.9 times slower compared to the control group. In comparison with eskuvit this value approaches 1. Taking into consideration the mechanism of the histamine action we can suggest that the extract from the leaves of Corylus avellana under research exhibits a pronounced effect on permeability of capillaries and microcirculation. The extract showed a moderate effect against the background of formalin and protein inflammation, but this index exceeded the index in the group with eskuvit by 170 seconds against the background of formalin inflammation. The results obtained indicate the presence of the capillary resistance action, and it is the cause for further research of the efficiency of the extract in the experimental pathology.
\end{abstract}

$\mathrm{V}$ aricose veins disease of the lower limbs is one of the most common cardiovascular diseases that progresses constantly, resulting in severe trophic changes with subsequent disturbance of the central hemodynamics and heart failure [2]. One of the major pathogenic links of varicose veins is disorder of the venous outflow; as a result of it venous hypertension occurs. Increased venous pressure causes adhesion of leukocytes to the endothelium of capillaries and the subsequent migration into the tissues. There is a gradual increase in capillary permeability and development of the tissue edema. Activated leukocytes release proteases and free radicals that cause damage of the endothelium of capillaries with development of significant disturbances in the microcirculation system and degradation of collagen fibres of a venous wall. As a result, an aseptic inflammation of the vein wall develops $[9,10]$.

Nowadays there is an urgent search for the substances that can inhibit the inflammatory process, and they should be based on the plant origin. A promising material is Corylus avellana, which is used in the folk medicine for varicose ulcers, capillary hemorrhages, gastrointestinal bleedings and other diseases [6]. According to the literature sources Corylus avellana contains phenolic compounds, which can cause of the anti-inflammatory and anti-edema action, reduce venous congestion of the capillaries, improve venous circulation, decrease the permeability of vascular walls and strengthen the capillaries $[1,4,6]$.

Since one of the mechanisms of inflammation is increase in the vascular permeability, the aim of L.M.Maloshtan - Doctor of Biology, professor, head of the Department of Physiology
and Human Anatomy of the National University of Pharmacy (Kharkiv)

O.V.Dorovskyy - Doctor of Economics, associate professor, head of the Department of Industrial Pharmacy and Economics of the Institute for Continuing Education of Pharmacy Professionals at the National University of Pharmacy (Kharkiv) our research was to study the effect of the thick extract from the leaves of Corylus avellana on the vascular tissue permeability in rats against the background of the inflammation process of various origins (with the help of the method by P.P.Golikov, 1964) [3].

\section{Materials and Methods}

The study object was the thick extract from the leaves of Corylus avellana, obtained at the Department of Chemistry of Natural Compounds of the National Pharmaceutical University under the supervision of professor Khvorost O.P. All studies were performed on 24 white outbred rats weighing 180-200 g with 6 rats in each group. The animals received standard food according to the current regulations [5]. They were treated according to the rules of the "European Convention for the protection of vertebrate animals used for experimental and scientific purposes" (Strasbourg, 1986).

The animals were divided into the following groups: Group 1 - is the control pathology treated with 
Table

\section{The effect of the thick extract from the leaves of Corylus avellana on the vascular tissue permeability by Golikov P.P. method, $1964(n=24)$}

\begin{tabular}{|c|c|c|c|c|c|}
\hline \multirow{2}{*}{ The experimental conditions } & \multirow{2}{*}{$\begin{array}{l}\text { Dose, } \\
\mathrm{mg} / \mathrm{kg}\end{array}$} & \multirow{2}{*}{ Index } & \multicolumn{3}{|c|}{$\begin{array}{l}\text { The time of the rats' skin staining under } \\
\text { the action of phlogogenic agents, } s\end{array}$} \\
\hline & & & Formalin & Protein & Histamine \\
\hline The control pathology & - & Tc & $504 \pm 27$ & $95 \pm 3$ & $124 \pm 10$ \\
\hline \multirow{2}{*}{$\begin{array}{l}\text { The thick extract of } \\
\text { Corylus avellana (once) }\end{array}$} & \multirow{2}{*}{60} & $\mathrm{Td}$ & $531 \pm 7 \#$ & $104 \pm 5$ & $150 \pm 6^{\# / \varphi}$ \\
\hline & & VPDI, \% & 0.2 & 9 & 17 \\
\hline \multirow{2}{*}{$\begin{array}{l}\text { The thick extract of } \\
\text { Corylus avellana ( } 5 \text { days) }\end{array}$} & \multirow{2}{*}{60} & $\mathrm{Td}$ & $820 \pm 17^{*} / \# / \varphi$ & $126 \pm 10^{*}$ & $241 \pm 34^{*}$ \\
\hline & & VPDI, \% & 38.5 & 25 & 48.5 \\
\hline \multirow{2}{*}{ Eskuvit (once) } & \multirow{2}{*}{10} & $\mathrm{Td}$ & $650 \pm 41^{*}$ & $118 \pm 11^{*}$ & $238 \pm 21^{*}$ \\
\hline & & VPDI, \% & 23 & 19 & 47 \\
\hline
\end{tabular}

Notes:

1) * - statistically significant differences compared to the control pathology, $\mathrm{p}<0.05$;

2) ${ }^{\#}$ - statistically significant differences compared to eskuvit, $10 \mathrm{mg} / \mathrm{kg}, \mathrm{p}<0.05$;

3) ${ }^{\varphi}$ - statistically significant differences compared to the thick extract of Corylus avellana (once), $60 \mathrm{mg} / \mathrm{kg}, \mathrm{p}<0.05$;

4) VPDI- is decrease of the vascular permeability index;

5) Tc - is the average time of appearance of colouring in the rats of the positive control group, s;

6) $\mathrm{Td}$ - is the average time of appearance of colouring in the rats treated with the thick extract of Corylus avellana and eskuvit, s.

distilled water; Group 2 - is the group of the animals received the extract from the leaves of Corylus avellana studied in its conditionally therapeutic dose of $60 \mathrm{mg} / \mathrm{kg}$ according to the clinical regimen (once); Group 3 - is the group of the animals received the extract in its conditionally therapeutic dose of $60 \mathrm{mg} / \mathrm{kg}$ in the medical and preventive regimen (for 5 days), Group 4 - is the group of the animals received the reference drug eskuvit tablets (the active ingredient: $0.04 \mathrm{~g}$ of the dry extract of horse chestnut fruits equivalent to the content of $50 \%$ escin manufactured by "Halychpharm", Ukraine). The reference drug was administered in the dose of $10 \mathrm{mg} / \mathrm{kg}$ calculated with reference to the daily human dose according to Rybolovlev [8].

The test procedure of the vascular tissue permeability was reproduced as follows: the rats weighing 170-220 g were anesthetized by the solution of thiopental in the dose of $35 \mathrm{mg} / \mathrm{kg}$, fixed on the operating table with a belly up, cut hair on the abdomen. The vein was uncovered on the right rear paw and $1 \%$ solution of trypan blue was injected in the dose of $2 \mathrm{ml} / \mathrm{kg}$. In $10 \mathrm{~min}$ after the intravenous injection of the dye into the abdominal region in the volume of $0.02 \mathrm{ml}$ the following phlogogenic substances were injected intradermally: undiluted egg white, $3 \%$ formalin and $0.1 \%$ solution of histamine. The animals were treated intragastrically with the thick extract of Corylus avellana in the dose of $60 \mathrm{mg} / \mathrm{kg}$ and the reference drug - eskuvit tablets in the dose of $10 \mathrm{mg} / \mathrm{kg}$ within 5 days. The last dose was injected on the day of the experiment $40 \mathrm{~min}$ before the testing. A separate group of animals received the extract studied in the dose of $60 \mathrm{mg} / \mathrm{kg}$ $40 \mathrm{~min}$ before the testing. The effect of the thick extract from the leaves of Corylus avellana on the vascular tissue permeability in rats has been assessed by the time of papules colouring (the animals' skin at the site of phlogogenic substances injection) in seconds.

Efficacy of the extract studied on the vascular tissue permeability on the background of its damage by inflammatory agents was assessed compared to the control pathology and the effect of the re- ference drug. The vascular permeability decrease index (VPDI) of drugs was calculated [3].

The statistical data processing was conducted using the Statistica 6.0 software package. Statistical analysis was performed using the Newman-Keuls test for the significance level of $\mathrm{P}<0.05$.

\section{Results and Discussion}

The state of the vascular permeability in the control pathology group was characterized by the following data: the fastest stained skin where protein was introduced (95 s); stained skin after the injection of histamine appeared later (124 s), then there was the formalin (504 s) papule (Table).

According to the literature sources different phlogogenic substances have different mechanisms of action on the capillary permeability. The action of histamine and protein develops quickly because they act on cells releasing inflammatory mediators (histamine, serotonin and kinin), and it causes microcirculatory disorders. The action of formalin develops slowly and is due to its effects on the endothelium of capillaries; as a re- 
sult, its ability to pass water and plasma proteins increases [7].

Under the effect of the sample of the Corylus avellana extract introduced once the reduction of the time of papules colouring was insignificant compared to the control. In the group received the extract studied for 5 days the decrease of the vascular permeability induced by phlogogenic substances was observed. The thick extract from the leaves of Corylus avellana showed the most pronounced vascular restorative effect during the experiment with histamine where papules colouring was 1.9 times slower compared to the control group, and in the group with protein - 1.3 times slower in comparison with the control pathology. In comparison with eskuvit these values approached 1. In the group with formalin they were 1.6 times slower compared to the control pathology group, and this index exceeded the index of the eskuvit group by $170 \mathrm{~s}$.

Taking into consideration the mechanism of action of the phlogogens used we can suggest that the extract from the leaves of $\mathrm{Co}$ rylus avellana studied in the medical and preventive regimen exhibits the pronounced effect on permeability of capillaries and microcirculation. Based on these results the conclusion can be made that the extract reduces permeability, restores microcirculation and exhibits the capillary protective action, which is not inferior to the action of the reference drug evskuvit by intensity, and against the background of formalin inflammation even exceeds it. Thus, the extract studied is able to strengthen capillary walls.

\section{CONCLUSIONS}

It has been found that under the effect of the thick extract from the leaves of Corylus avellana in the medical and preventive regimen the time of papules colouring induced by all phlogogenic substances reduces. The most pronounced vessel strengthening effect of the thick extract was revealed during the experiment with histamine where papules colouring was 1.9 times slower compared to the control pathology group.
During the experiment with protein it was 1.3 times slower in comparison with the control pathology. In comparison with eskuvit these values approached 1. During the experiment with formalin papules colouring was 1.6 times slower compared to the control pathology group, and this index exceeded the index of the eskuvit group by 170 s. Therefore, taking into consideration the mechanism of action of phlogogenic substances we can suggest that the extract from the leaves of $\mathrm{Co}$ rylus avellana under research exhibits the most pronounced effect on permeability of capillaries and microcirculation, as well as reveals the protective action on the endothelium of capillaries. Based on these results the conclusion can be made about the presence of the capillary protective action and positive effects on the vascular tissue permeability of the thick extract from the leaves of Corylus avellana in rats, and it is the reason for the further study of the effectiveness of the extract under conditions of the experimental pathology.

\section{REFERENCES}

1. Азарова О.В., Галактионова Л.П. // Химия растит. сырья. - 2012. - №4. - С. 61-78.

2. Беленцов С.М., Эктова М.В., Попов А.Н. // Флеболимфол. - 2006. - №27. - С. 11-14.

3. Голиков П.П. // Фармакол. и токсикол. - 1964. - №6. - С. 742-743.

4. Гонтова Т.М., Хворост О.П., Беліков В.В. та ін. // Фармац. журн. - 1995. - №6. - С. 65-66.

5. Западнюк М.П., Западнюк В.И., Захария Е.А. Лабораторные животные. Использование в эксперименте. - К.: Высш. шк., 1983. - 382 с.

6. Мовсумов И.С., Юсифова Д.Ю., Гараев Э.А. // Химия растит. сырья. - 2013. - №4. - С. 259-261.

7. Регеда М.С., Бойчук Т.С., Бондаренко Ю.І., Регеда М.М. Запалення - типовий патологічний процес. - 2-ге вид., доп. та перероб. - Львів, 2013. - 148 с.

8. Рыболовлев Ю.Р., Рыболовлев Р.С. Дозирование веществ для млекопитающих по константам биологической активности // Докл. АН СССР. - 1979. - Т. 247, №6. - С. 1513-1516.

9. Buján. J., Pascual G., Bellón J.M. // Phlebolymphol. - 2008. - Vol. 15, №4. - P. 123.

10. Raffetto J.D., Khalil R.A. // Phlebol. - 2010. - Vol. 23, №10. - P. 85-98. 


\section{ДОСЛІДЖЕННЯ ВПЛИВУ ГУСТОГО ЕКСТРАКТУ З ЛИСТЯ ЛІЩИНИ ЗВИЧАЙНОЇ НА СУДИННО-ТКАНИННУ ПРОНИКНІСТЬ}

Л.М.Малоштан, Г.С.Каленіченко, О.В.Доровський*

Національний фармацевтичний університет, Інститут підвищення кваліфікації спеціалістів фбармації Національного фармацевтичного університету*

Ключові слова: екстракт з листя ліщини звичайної; лікарські рослини; варикозна хвороба; капілярозміцнююча активність

Досліджено вплив густого екстракту з листя ліщини звичайної (Corylus avellana) на проникність капілярів шкіри щурів. Вплив густого екстракту з листя ліщини на судинно-тканинну проникність у щурів оцінювали за часом забарвлення папул шкіри тварин у місці ін'єкції флогогенних речовин у секундах. В якості флогогенів застосовували формалін, гістамін, білок, які мають різні механізми дії на проникність капілярів. У тварин, яким вводили досліджуваний екстракт в умовно-терапевтичній дозі 60 мг/кг, спостерігалося зменшення судинноі проникності, викликаної усіма флогогенними речовинами. Визначено, що найбільш виражений судиннозміцнюючий ефект екстракт проявив відносно гістамінового запалення, де фарбування папули було в 1,9 рази повільніше порівняно з контрольною групою, а порівняно з ескувітом даний показник наближався до 1. Враховуючи механізм дії гістаміну, можна припустити, що досліджуваний екстракт виявляє виражену дію на проникність капілярів та мікроциркуляцію. Відносно формалінового та білкового запалення екстракт проявив помірний ефект, однак перевищив показник у групі ескувіту на 170 с в умовах формалінового запалення. Отримані дані свідчать про наявність капілярозміцнюючої дії, що є приводом для подальшого дослідження ефективності екстракту за умов експериментальної патології.

\section{ИССЛЕДОВАНИЕ ВЛИЯНИЯ ГУСТОГО ЭКСТРАКТА ИЗ ЛИСТЬЕВ ЛЕЩИНЫ ОБЫКНОВЕННОЙ НА СОСУДИСТО- ТКАНЕВУЮ ПРОНИЦАЕМОСТЬ}

Л.Н.Малоштан, А.С.Калениченко, А.В.Доровской*

Национальный фармацевтический университет, Институт повышения квалификации специалистов фармации Национального фармацевтического университета*

Ключевые слова: экстракт из листьев лещины обыкновенной; лекарственные растения; варикозная болезнь; капилляроукрепляющая активность

Исследовано влияние густого экстракта из листьев лещины обыкновенной (Corylus avellana) на проницаемость капилляров кожи крыс. Влияние густого экстракта из листьев лещины на сосудисто-тканевую проницаемость у крыс оценивали по времени окрашивания папул кожи животных в месте инъекции флогогенных веществ в секундах. В качестве флогогенов применяли формалин, гистамин, белок, которые имеют разные механизмы действия на проницаемость капилляров. В группе животных, которым вводили исследуемый экстракт в условно-терапевтической дозе 60 мг/кг, наблюдалось уменьшение сосудистой проницаемости, вызванной всеми флогогенными веществами. Определено, что наиболее выраженный сосудоукрепляющий эффект экстракт проявил относительно гистаминового воспаления, где окраска папулы была в 1,9 раза медленнее по сравнению с контрольной группой, а по сравнению с эскувитом данный показатель приближался к 1. Учитывая механизм действия гистамина, можно предположить, что исследуемый экстракт оказывает выраженное действие на проницаемость капилляров и микроциркуляцию. Относительно формалинового и белкового воспаления экстракт проявил умеренный эффект, однако превысил показатель в группе эскувита на 170 с в условиях формалинового воспаления. Полученные данные свидетельствуют о наличии капилляроукрепляющего действия, что является поводом для дальнейшего исследования эффективности экстракта в условиях экспериментальной патологии.

Address for correspondence:

Received in 23.09.2015

12, Melnikov Str., Kharkiv, 61002, Ukraine.

Tel. (57) 706-30-73. E-mail: physio@nuph.edu.ua.

National University of Pharmacy 